ҚАЗАҚСТАН РЕСПУБЛИКАСЫ

ҰЛТТЫҚ ҒЫЛЫМ АКАДЕМИЯСЫНЫН

АБАЙ АТЫНДАҒЫ ҚАЗАҚ ҰЛТТЫҚ

ПЕДАГОГИКАЛЫҚ УНИВЕРСИТЕТІНІҢ

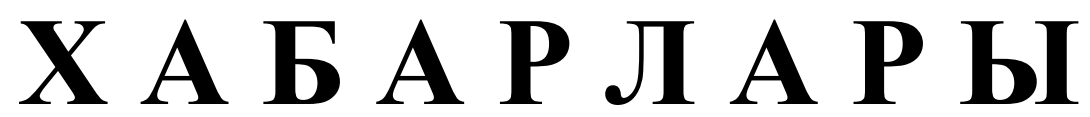

\section{ИЗВЕСТИЯ}

НАЦИОНАЛЬНОЙ АКАДЕМИИ НАУК РЕСПУБЛИКИ КАЗАХСТАН

КАЗАХСКИЙ НАЦИОНАЛЬНЫЙ

ПЕДАГОГИЧЕСКИЙ УНИВЕРСИТЕТ ИМ. АБАЯ

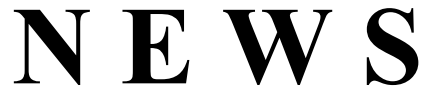

OF THE NATIONAL ACADEMY OF SCIENCES OF THE REPUBLIC OF KAZAKHSTAN

ABAY KAZAKH NATIONAL PEDAGOGICAL UNIVERSITY

ҚОҒАМДЫҚ ЖӘНЕ ГУМАНИТАРЛЫҚ ҒЫЛЫМДАР СЕРИЯСЫ

СЕРИЯ ОБЩЕСТВЕННЫХ И ГУМАНИТАРНЫХ НАУК

SERIES OF SOCIAL AND HUMAN SCIENCES

\author{
6 (322) \\ ҚАРАША - ЖЕЛТОҚСАН 2018 ж. \\ НОЯБРЬ - ДЕКАБРЬ 2018 Г. \\ NOVEMBER - DECEMBER 2018 \\ ИЗДАЕТСЯ С ЯНВАРЯ 1962 ГОДА \\ PUBLISHED SINCE JANUARY 1962 \\ ЖЫЛЫНА 6 РЕТ ШЫҒАДЫ \\ ВЫХОДИТ 6 РАЗ В ГОД \\ PUBLISHED 6 TIMES A YEAR
}

1962 ЖЫЛДЫҢ ҚАНТАР АЙЫНАН ШЫҒА БАСТАҒАН 
Ба с ре дактор

ҚР ҰҒА кұрметті мүшесі

Балықбаев Т.O.

Р е д а ц и я а лқ а сы:

экон. ғ. докторы, проф., ҚР ҰҒА академигі Баймұратов У.Б.; тарих ғ. докторы, проф., ҚР ҰҒА академигі Байпақов К.М.; филос. ғ.докторы, проф., ҚР ҰҒА академигі Есім Г.Е.; фил. ғ. докторы,, проф., ҚР ҰҒА академигі Қирабаев С.С.; эк. ғ. докторы, проф., ҚР ҰҒА академигі Кошанов А.К.; эк.ғ. докторы, проф., ҚР ҰҒА академигі Нәрібаев К.Н. (бас редактордың орынбасары); филос. ғ.докторы, проф., ҚР ҰҒА академигі Нысанбаев А.Н.; заң ғ. докторы, проф., ҚР ҰҒА академигі Сәбікенов С.Н.; заң ғ. докторы, проф., ҚР ҰҒА академигі Сүлейменов М.К.; эк. ғ. докторы, проф., ҚР ҰҒА академигі Сатыбалдин С.С.; тарих ғ. докторы, проф., ҚР ҰҒА академик Әбжанов Х.М.; тарих ғ. докторы, проф., ҚР ҰҒА корр. мүшесі Әбусеитова М.Х.; тарих ғ. докторы, проф., ҚР ҰҒА академик Байтанаев Б.А.; филол. ғ. докторы, проф., ҚР ҰҒА корр. мүшесі Жақып Б.А.; фил. ғ. докторы, проф., академик НАН РК Қалижанов У.К.; филол. ғ. докторы, проф., ҚР ҰҒА академик Қамзабекұлы Д.; тарих ғ. докторы, проф., ҚР ҰҒА академик Қожамжарова Д.П.; тарих ғ. докторы, проф., ҚР ҰҒА академик Койгелдиев М.К.; фил. ғ. докторы, проф., ҚР ҰҒА корр. мүшесі Кұрманбайұлы Ш.; тарих ғ. докторы, проф., ҚР ҰҒА корр. мүшесі Таймағанбетов Ж.К.; социол. ғ. докторы, проф., ҚР ҰҒА корр. мүшесі Шәукенова 3.К.; фил. ғ. докторы, проф., КР ҰҒА корр. мүшесі Дербісәлі А.; саяси. ғ. докторы, проф., Бижанов А.К., тарих ғ. докторы, проф., Кабульдинов 3.Е.; фил. ғ. докторы, проф., ҚР ҰҒА корр мүшесі Қажыбек Е.3.

\section{Р едакция ке н е с i:}

Молдова Республикасының ҰҒА академигі Белостечник Г. (Молдова); Әзірбайжан ҰҒА академигі Велиханлы Н. (Азербайджан); Тәжікстан ҰҒА академигі Назаров Т.Н. (Тәжікстан); Молдова Республикасының ҰҒА академигі Рошка А. (Молдова); Молдова Республикасының ҰҒА академигі Руснак Г. (Молдова); Әзірбайжан ҰҒА корр. мүшесі Мурадов Ш. (Әзірбайжан); Әзірбайжан ҰҒА корр. мүшесі Сафарова 3. (Әзірбайжан); э. ғ. д., проф. Василенко В.Н. (Украина); заң ғ. докт., проф. Устименко В.А. (Украина)

«Қазақстан Республикасы Ұлттық ғылым академиясының Хабарлары. Қоғамдық және гуманитарлық ғылымдар сериясы». ISSN 2224-5294

Меншіктенуші: «Қазақстан Республикасының Ұлттық ғылым академиясы» РҚБ (Алматы қ.)

Қазақстан республикасының Мәдениет пен ақпарат министрлігінің Ақпарат және мұрағат комитетінде 30.04.2010 ж. берілген № 10894-Ж мерзімдік басылым тіркеуіне қойылу туралы куәлік

Мерзімділігі: жылына 6 рет.

Тиражы: 500 дана.

Редакцияның мекенжайы: 050010, Алматы қ., Шевченко көш., 28, 219 бөл., 220, тел.: 272-13-19, 272-13-18, http://nauka-nanrk.kz. social-human.kz

(C) Қазақстан Республикасының Ұлттық ғылым академиясы, 2018

Типографияның мекенжайы: «Аруна» ЖК, Алматы қ., Муратбаева көш., 75. 
Главный редактор

Почетный член НАН РК

T.O. Балыкбаев

Р е дак ци онн а я коллег и я:

докт. экон. Н., проф., академик НАН РК У.Б. Баймуратов; докт. ист. н., проф., академик НАН РК К.М. Байпаков; докт. филос. Н., проф., академик НАН РК Г.Е. Есим; докт. фил. Н., проф., академик НАН РК С.С. Кирабаев; докт. экон. Н., проф., академик НАН РК А.К. Кошанов; докт. экон. Н., проф., академик НАН РК К.Н. Нарибаев (заместитель главного редактора); докт. филос. н., проф., академик НАН РК А.Н. Нысанбаев; докт. юр. Н., проф., академик НАН РК С.Н. Сабикенов; докт. юр. н., проф., академик НАН РК М.К. Сулейменов; докт. экон. Н., проф., академик НАН РК С.С. Сатубалдин; докт. ист. н., проф., академик НАН РК Х.М. Абжанов; докт. ист. н., проф., чл.-корр. НАН РК М.Х. Абусеитова; докт. ист. н., проф., академик НАН РК Б.А. Байтанаев; докт. фил. н., проф., чл.-корр. НАН РК Б.А. Жакып; докт. фиолол. н., проф., академик НАН РК У.К. Калижанов; докт. фил. н., проф., академик НАН РК Д. Камзабекулы; докт. ист. н., проф., академик НАН РК Д.П. Кожамжарова; докт. ист. н., проф., академик НАН РК М.К. Койгельдиев; докт. филол. н., проф., чл.-корр. НАН РК Ш. Курманбайулы; докт. ист. н., проф., чл.корр. НАН РК Ж.К. Таймаганбетов; докт. социол. н., проф., чл.-корр. НАН РК З.К. Шаукенова; д. филол. н., проф., чл.-корр. НАН РК А. Дербисали; доктор политических наук, проф., Бижанов А.К.; доктор ист. наук, проф., Кабульдинов 3.Е.; доктор филол. н., проф., член-корр. НАН РК Қажыбек Е.3.

Р е дак ци онны й с ов ет

академик НАН Республики Молдова Г. Белостечник (Молдова); академик НАН Азербайджанской Республики Н. Велиханлы (Азербайджан); академик НАН Республики Таджикистан Т.Н. Назаров (Таджикистан); академик НАН Республики Молдова А. Рошка (Молдова); академик НАН Республики Молдова Г. Руснак (Молдова); чл.-корр. НАН Азербайджанской Республики Ш. Мурадов (Азербайджан), член-корр. НАН Азербайджанской Республики 3.Сафарова (Азербайджан); д. э. н., проф. В.Н. Василенко (Украина); д.ю.н., проф. В.А. Устименко (Украина)

Известия Национальной академии наук Республики Казахстан. Серия общественных и гуманитарных наук. ISSN 2224-5294

Собственник: РОО «Национальная академия наук Республики Казахстан» (г. Алматы)

Свидетельство о постановке на учет периодического печатного издания в Комитете информации и архивов

Министерства культуры и информации Республики Казахстан № 10894-Ж, выданное 30.04.2010 г.

Периодичность 6 раз в год

Тираж: 500 экземпляров

Адрес редакции: 050010, г. Алматы, ул. Шевченко, 28, ком. 219, 220, тел. 272-13-19, 272-13-18, www:nauka-nanrk.kz / social-human.kz

(C) Национальная академия наук Республики Казахстан, 2018 г.

Адрес типографии: ИП «Аруна», г. Алматы, ул. Муратбаева, 75

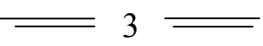


Chief Editor

\section{Honorary member of NAS RK \\ Balykbayev T.O}

Editorial board:

Doctor of economics, prof, academician of NAS RK Baimuratov U.B.; doctor of history, prof, academician of NAS RK Baipakov K.M.; doctor of philosophy, prof, academician of NAS RK Esim G.E.; doctor of philology, prof, academician of NAS RK Kirabayev S.S.; doctor of economics, prof, academician of NAS RK Koshanov A.K.; doctor of economics, prof, academician of NAS RK Naribayev K.N. (deputy editor-in-chief); doctor of philosophy, prof, academician of NAS RK Nyssanbayev A.N.; doctor of law, prof, academician of NAS RK Sabikenov S.N.; doctor of law, prof, academician of NAS RK Suleymenov M.K.; doctor of economy, prof, academician of NAS RK Satybaldin S.S.; doctor of history, prof, academician of NAS RK Abzhanov H.M; doctor of history, prof, corresponding member of NAS RK Abuseitova M.H.; doctor of history, prof, academician of NAS RK Baitanaev B.A.; doctor of philology, prof, corresponding member of NAS RK Zhakyp B.A.; doctor of philology, prof, academician of NAS RK Kalizhanov U.K.; doctor of philology, prof, academician of NAS RK Hamzabekuly D.; doctor of history, prof, academician of NAS RK Kozhamzharova D.P.; doctor of history, prof, academician of NAS RK Koigeldiev M.K.; doctor of philology, prof, corresponding member of NAS RK Kurmanbaiuly Sh.; doctor of history, prof, academician of NAS RK Taimaganbetov J.K.; doctor of sociology, prof, corresponding member of NAS RK Shaukenova Z.K.; doctor of philology, prof, corresponding member of NAS RK Derbisali A.; doctor of political science, prof Bizhanov A.K; doctor of History, prof Kabuldinov Z.E.; doctor of philology, prof, corresponding member of NAS RK Kazhybek E.Z.

\section{Editorial staff:}

Academician NAS Republic of Moldova Belostechnik.G (Moldova); Academician NAS Republic of Azerbaijan Velikhanli N. (Azerbaijan); Academician NAS Republic of Tajikistan Nazarov T.N. (Tajikistan); Academician NAS Republic of Moldova Roshka A. (Moldova) Academician NAS Republic of Moldova Rusnak G. (Moldova); Corresponding member of the NAS Republic of Azerbaijan Muradov Sh. (Azerbaijan); Corresponding member of the NAS Republic of Azerbaijan Safarova Z. (Azerbaijan); Associate professor of Economics Vasilenko V.N. (Ukraine), Associate professor of Law Ustimenko V.A. (Ukraine)

News of the National Academy of Sciences of the Republic of Kazakhstan. Series of Social and Humanities. ISSN 2224-5294

Owner: RPA "National Academy of Sciences of the Republic of Kazakhstan" (Almaty)

The certificate of registration of a periodic printed publication in the Committee of information and archives of the Ministry of culture and information of the Republic of Kazakhstan N 10894-Ж, issued 30.04.2010

Periodicity: 6 times a year

Circulation: 500 copies

Editorial address: 28, Shevchenko str., of. 219, 220, Almaty, 050010, tel. 272-13-19, 272-13-18, www:nauka-nanrk.kz / social-human.kz

(C) National Academy of Sciences of the Republic of Kazakhstan, 2018

Address of printing house: ST "Aruna", 75, Muratbayev str, Almaty 
N E W S

OF THE NATIONAL ACADEMY OF SCIENCES OF THE REPUBLIC OF KAZAKHSTAN

SERIES OF SOCIAL AND HUMAN SCIENCES

ISSN 2224-5294

https://doi.org/10.32014/2018.2224-5294.60

Volume 6, Number 322 (2018), $241-250$

УДК 303.633.4(64:51)+327.821

\author{
Ye.I. Rudenko
}

R.B. Suleimenov Institute of Oriental Studies, Almaty, Kazakhstan

E-mail: lenochka_rud@mail.ru

\title{
MISPERCEPTION BETWEEN THE STATES OF CENTRAL AND SOUTH ASIA AS A 'SOFT POWER' AND INFORMATION SECURITY ISSUE
}

\begin{abstract}
The paper aims at discussion of certain inaccuracies and incorrectness in perception by representatives of India and Pakistan of various aspects of internal and external situation within and around the Central Asian republics, with special emphasis upon Kazakhstan. Methodologically, the work is performed upon critical analysis of numerous research and expert writings by representatives of two leading South Asian countries. The issues of internal and external security, religious factor and economy in Central Asia are covered among others. It is shown that, mostly due to objective reasons, outdated materials, including these created by often biased Western and Russian authors, as well as own mistaken convictions and conjectures are regularly involved to describe both previous and current situation in the states of Central Asia. At that, attempts of South Asian intellectuals aimed at overcoming this problem are also considered. Finally, it is argued that the factor of 'soft power' and hence, of information security, in Central Asian countries indeed suffers enough, and that on the basis of discussed examples as well as experience offered by South Asian states all such inaccuracies in perception should be properly taken into account with the view of their mitigation or/and elimination.
\end{abstract}

Keywords: South and Central Asia, perverted perception, soft (smart) power, information security, cultural (public) diplomacy, threats.

Introduction. In both trivial and scientific consciousness, the theory and practice of international relations often implies and, therefore, predominantly focuses upon their political and economic constituents. Consequently, advances or failures of any state in the international arena are considered, analyzed and projected from mere point of view of current status and prospect of development of its political and economic relations with other states and non-state actors. At that, politics usually stands for general - smooth or tense - situation in interstate relations, for a number of highest level visits and signed 'strategic' documents, etc., while economy implies the value of trade turnover, mutual inclusion of economic entities of one state into the economic structures of another and so on.

However, (and it is quite well-known that) both the theoretical concepts of postmodern era and the actual practice prove that a very important aspect of international relations is related to ideology, the 'soft/smart power' or, as author intends to discuss in this paper, the mutual perception of one state (or a whole region) by another state (or region).

Indeed, as Daya Kishan Thussu, an England-based Indian Professor of International Communication and Co-Director of the India Media Centre aptly wrote in his book that "though vaguely defined and rather amorphous, the concept of soft power has been adopted or adapted by countries around the world as a component of foreign policy strategy, ... [since] mere possession of resources [of cultural and intellectual wealth] does not make a country attractive on the world stage; these assets need to be translated into influencing the behaviour of other states and stakeholders, requiring a concerted effort by policy makers" [1, pp. 4, 12]. And Mr. Sartaj Aziz, a Pakistani economist and strategist, have once reasonably noted that "the concept of 'soft power', although unveiled by Joseph Nye in the 90's, has traditionally existed as a reality as well ... we can understand this concept of 'soft power' as the use of national resources that can 
lead to a nation's/group's/organisation's ability to affect others through the co-optive means of framing the agenda, persuading and eliciting positive attraction in order to obtain preferred outcome" [2, p. 5].

As a result, such phenomenon of 'soft power', or mutual perception, - at the level of society and at the state level - often turns out extremely decisive and largely predetermines either success or failure in the development of bilateral and multilateral political and economic relations. The fact how one state or region is seen to / perceived by another state or region impacts the subsequent interest in establishing and promoting constructive relations between them in various fields. And sometimes fortunately but more often unfortunately this perception does not always reflect the actual situation. Often, it can be based upon information that was true but misunderstood, on information that was initially incorrect (for example, obtained in a distorted form from third parties), and even upon conjectures in case of elementary shortage of objective knowledge about each other.

This problem exists between the states of Central and South Asia among others (here the emphasis is made primarily on India and then Pakistan). At that, the paper aims at considering issues of perception of the Central Asian region and its separate state - the Republic of Kazakhstan, which is yet seems to be practically 'inseparable' from this region, in the eyes of Indian and Pakistani analysts. On the one hand, Kazakhstan itself has quite enough information only about the period of Indian history until the beginning of economic reforms of the 1990's; even less is known here about Pakistan. For the case of India, this could be attributed to the collapse of the Soviet Union, curtailment of Soviet-Indian ties and temporary dropout of India from the 'closest priorities' of Kazakhstan's foreign policy. A problem with 'ignorance' of Pakistan could be explained by the fact that even during Soviet period there were no similar close ties with him in principle. On the other hand, India and Pakistan, as proves analysis of public opinion and works of their scientists and experts, did and still do not have sufficient adequate information about Kazakhstan and other countries of the Central Asian region. They received and largely continue to receive such information from third parties and often rely upon outdated or/and biased returns, perceiving them as characterizing the actual current situation.

Certainly, in recent years there is observed an increased all-round interest of these two South Asian states towards the Central Asian region and, as a result, the desire to obtain and accumulate as much extensive and reliable information about it as possible. Thus, according to the author's observations, since 2002 there has been expansion in more or less objective knowledge of Indians and Pakistanis about Kazakhstan. A major role in this was played, in particular, by holding in June of that year in Almaty of the Conference on Interaction and Confidence-Building Measures in Asia (CICA) member states meeting, which received wide coverage in Indian and Pakistani mass media. There is now also seen an increase in the number of Indian and Pakistani specialists dealing not just with 'Russia and the neighbouring countries' in general and even not only with Central Asia as in all respects a 'single' region as it was practiced before, but with its individual states. It should also be noted that strategically important for the whole South Asian region issue such as the need for ensuring energy security contributes to the desire for receipt of more reliable (albeit often again outdated) information on hydrocarbon reserves in Kazakhstan and on infrastructure projects in Kazakhstani energy sector. And yet, the perception of this state and the Central Asian region as a whole neither by general public nor by experts and politicians of India and Pakistan can still be considered fully correct.

Methods. As one can infer from the above-stated propositions, theoretically the concepts of 'soft power', including mutual perception as its integral constituent, which in their turn highly impact the factor of information security (or the safety of national - being a combination of balanced individual, social, country- and sometimes region-wide - interests in informational-psychological sphere, including subjective desire and objective need to be correctly, adequately and impartially understood and perceived by various actors of the world community), underlie the study summarized in this paper. Methodologically, the work is performed and its conclusions and results are obtained through the critical analysis (along with contrastive comparison with Russian and Western sources as well as with naturally existing reality) of numerous research and expert writings by representatives of two leading South Asian countries.

Results. An analysis of numerous works by Indian and Pakistani authors written between the late 1990's and the middle of 2010's [for more detailed information and a list of analyzed works with quotes by Indian authors see: 3, pp. 129-138; 4] proves that among the main problems of such a distorted

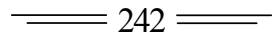


perception of the Central Asian countries on the side of the two leading states of South Asia one can mention the following.

First of all, it should be noted that Indians and Pakistanis, though similar to representatives of many other Western and Eastern states, still perceive Kazakhstan as a part and parcel of all-round single region of Central Asia, which has only minor features that distinguish it from other parts of the 'Central Asian whole'. At that, in case of India, Pakistan and other states of the Asian continent and the 'third' world in general, such perception is associated with characteristics once given to Central Asian region by Western experts.

In general, as demonstrates analysis of references in writings of Indian and Pakistani experts, the works by European, American and even Russian researchers are involved by them rather actively and with generally uncritical approach towards information which they offer. And in most foreign studies, despite their considerable variety, there is clearly seen analogous tendency of non-division of individual states of Central Asia, sometimes even in terms of their key political and economic indicators that, as a result, determines the nature of attitude of foreign scientists towards the current state of affairs within this region. Such a non-division of separate Central Asian states is in turn associated with certain ethnic-linguistic, confessional, cultural-civilizational and historical aspects. The latter implies the existence of a single Central Asia during the functioning of the Great Silk Road, within the Russian Empire and then the Soviet Union (USSR). Moreover, taking into account the fact that the states of South Asia were active subjects of trade and cultural activities on the Great Silk Road and, though passive, participants of struggle between the Russian and the British Empires for domination in Central Asia, and also allowing for the close SovietIndian ties (and during all these periods Central Asia interacted with Indian subcontinent as a comprehensive whole), this inaccuracy in perception can be considered to some extent explainable.

In this regard, some Indian and Pakistani researchers argue that during the Soviet period the entire Central Asian region was viewed by everybody as some large, unchanging and homogeneous space, and only after the collapse of the USSR it became possible to see certain differences between its five republics. Other researchers from India and Pakistan, on the contrary, believe that Central Asia, which has always been invariably unified, was artificially divided into separate state entities only during the Soviet period, and that indivisibility remains its inalienable feature. Of some significance here is also the resource and geographic factor; thus, according to Kashmiri researcher G.M. Mir, 'it is obvious that the resource structure, especially that of water-cum-hydrocarbon resources of Central Asian states, is so interwoven and intensely interdependent - making the whole region one complete economic zone' [5, p. 247].

At the same time, it is important to emphasize that both Indians and Pakistanis perceive Central Asia as a single region because of the abovementioned stereotypes which have developed over the centuries, and not because they are indeed interested in 'making' Central Asia one and inseparable whole. So, such a perception of this region by representatives of South Asia has nothing in common, in particular, with the American concept of Greater Central Asia once proclaimed by Frederick Starr, on the basis of which the unification of this region (plus Xinjiang, Mongolia and Afghanistan) indeed seems desirable [see 6].

An Annual Report of the Indian Ministry of Defence for years 2000-2001 offers a striking example of perception of our region once existed in Indian official circles. Thus, it stated that Central Asia has entered the world arena as a distinct geo-political entity arousing interest of the entire world community, that the region disposes of vast untapped resources of oil, gas and strategic minerals, and that drawing in Central Asian republics is, therefore, a significant factor in ensuring Indian security [7, p. 7]. A reference to this assertion can as before be found in much later works of some Indian researchers who characterize the current state of affairs in Central Asia. Moreover, the most recent report of the same Ministry asserts that "India's interests in Central Asia are based on its geostrategic location, presence of abundant energy and natural resources as well as age-old historical and cultural ties. The region continues to be targeted by radical terrorist groups that seek to undermine the secular regimes" $[8, p .5]$. Thus, the latter just in other words almost repeats the former's statement of sixteen years' prescription.

It should be accentuated here that in general these three aspects of perception - the overall unity of Central Asian region, its importance, first of all, in terms of local raw materials, and extrinsic interest in the region primarily on this very basis are, of course, characteristic not only for South Asian states. Therefore, the above statements do not at all mean that only they look down upon the region as a whole and on Kazakhstan in particular just as on object(s) suitable for mere solving of their own economic 
problems. Not at all - their interest in this region, according to the sayings of Indians and Pakistanis themselves, has always been related firstly to political partnership and secondly to economic cooperation. But all the same, consideration of this unpleasant matter of perception expressed in works by South Asian scholars should become an essential element of foreign policy of Central Asian republics. In this regard, they need to elaborate and consistently implement a strategy of appropriate self-positioning in the world arena, first of all, as separate independently developing states only geographically located in a single region but having many differences among themselves, actively seeking to move away from the rawmaterial orientation of their economies and deliberately approaching towards selection of suitable partners for mutually beneficial cooperation.

Unfortunately, judgments about Central Asia as a single region also relate to the overall domestic political situation in its separate states, to the issues of religion, social development, legal and institutional points and other aspects. Perhaps the only positive exception noted by both Indian and Pakistani authors is a difference in economic development and foreign policy orientation of every particular state within this region. In almost all other cases, Central Asian republics as a whole are described as states politically not very stable, dependent in their economic development primarily on possession of natural resources, ethnically dangerously diverse, with predominantly Muslim population (with respectively more negative nuance for India and more positive for Pakistan), etc.

If to discuss these provisions in more detail, one should note that this view of Indian and Pakistani public and academic communities upon situation in the states of Central Asia predetermines a number of established opinions about them.

A Point of Islam. As a rule, Indians (of course, to a greater extent comparing to Pakistanis) tend to exaggerate the role of Islam in the social and political life of Central Asian states. An explanation of this can be found in the situation that arose after the collapse of the USSR and, as a consequence, the cessation of Soviet-Indian relations. Being almost entirely surrounded by Muslim states or regions with predominantly Muslim population (such as Xinjiang Uygur Autonomous Region of China) and having lost former support of the religiously neutral Soviet Union, India was to certain extent scared of the growing role of Islamic factor in its Central Asian 'extended neighbourhood'. A number of circumstances have even more contributed to such a concern in India.

Firstly, an immediate stirring up of efforts of Pakistan, Iran and Turkey to include the newly independent countries of Central Asia into the orbit of their ideological influence on the basis of religious factor, as well as an entry of Central Asian states into the 'Muslim' Organization of Economic Cooperation. Thus, yet in the 2000's, many in India were confident that with the appearance in 1991 of five nominally Muslim neighbours, Pakistani politicians drew in their minds the 'arch of security' stretching from Pakistan to Turkey through Central Asia being perceived as Asian 'Muslim heart'.

Secondly, of considerable importance was economic crisis in Central Asian republics that followed the collapse of the USSR. Thus, some temporary popularity of radical Hizb ut-Tahrir in Central Asia was seen by Indians in that a significant part of local population is young, unemployed, poorly educated and hoping that the establishment of 'caliphate' would be a miraculous solution to all their problems.

Thirdly, a not well-grounded opinion of Western experts and the public at large that the Central Asian republics are merely doomed to turn into radical Islamic states has also negatively influenced Indian perception of religious situation within this region.

Increased attention was and still is also paid to the issue of external Islamic threat - combined with terrorism, drug trafficking and the Afghan problem - to the Central Asian states, which Indians (again much more comparing to Pakistanis) tend to exaggerate. Undoubtedly, to a certain extent this opinion should be considered correct. However, in this case once more within the concept of 'indivisible' Central Asia, Tajikistan (bordering Afghanistan), the regions of Uzbekistan and Kyrgyzstan adjacent to the Fergana Valley and Kazakhstan (where situation cannot be characterized so dramatically) are put on the same plane. In general, as for opinion about the spread of Islamic threat specifically in Kazakhstan, one can make two assumptions. Either in such alarming conclusions, in particular, of Indian experts Kazakhstan is 'conventionally' excluded from the usual concept of Central Asia, or declarative statements of Kazakhstani officials themselves about an 'all-embracing threat of Islamic extremism' are too literally perceived by the states of South Asia. Despite by nowadays India (as well as certain other states) has somewhat calmed down since she saw that her apprehensions about the radical Islamization of five

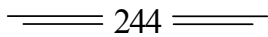


Central Asian republics turned intrinsically groundless, anyway, it is unlikely that at least in terms of information security Kazakhstan gains whatever from its perception as a state that is really vulnerable to the spread of radical Islam.

A Point of Intra- and Interstate Insecurity of Central Asian Republics. Since the acquisition of independence by Central Asian states, Indians (and again to somewhat lesser extent Pakistanis) were uneasy about their internal social and political stability. In particular, this related and relates to the status of opposition circles perceived as powerless and having almost no rights (here again the opinion of Western political scientists about 'anti-democratic' situation in Central Asian republics played its significant distorting role). Thus, many Indians for a long time believed that only in post-civil-war Tajikistan the status of opposition is close to the desired, while other four republics have not yet achieved enough success in this regard. Fortunately, if in their earliest works Indian authors expressed real concerns about political regimes in Central Asia and argued about desirability of India's transfer of its experience in building democratic states, then subsequently a mental situation has partly changed and Indian researchers and politicians now mostly believe that there is no urgent necessity in this for Central Asian states, who indeed can decide on their own what degree of democracy they actually need. At present, for India the main thing is that any regimes in Central Asia be capable to provide stability in their respective states and overall region for a more smooth and intensive cooperation between them and India, again first and foremost within the energy sector. However, it should nevertheless be borne in mind that this Indian (as well as global) opinion about non-democratic nature of state regimes in Central Asia remained unchanged, and only the attitude towards this fact has varied.

In connection with the abovementioned, the representatives of South Asian states have not been so much surprised with the so-called 'colour revolutions' in the post-Soviet space, in particular, the change of power in Kyrgyzstan as well as the Andijan events in Uzbekistan. On the contrary, taking into account the view of Pakistani and especially Indian scientists and politicians on Central Asia as 'politically unstable region', these events could be considered predictable and even expectable for them. (At the same time, it should undoubtedly be noted that the development of events under such scenario has always been more than undesirable for India and Pakistan, for it would have been the realization of the worst forecast for the possible unfolding of political situation in the Central Asian republics, and therefore, the mentioning of this problem in the writings by analysts of these two South Asian countries should be perceived as not mere statement of fact, but as apprehension and warning). Thus, keeping in mind an example of the civil war in Tajikistan, Indians still believe that stability and internal security in all the Central Asian states if not completely then at least largely depends on external factors: on the 'great game' of world powers, on transnational phenomena such as terrorism, extremism, Islamic fundamentalism, etc. Until now, quite many in South Asia tend to believe that Central Asian republics are weak and having virtually no capability to independently (or on regional level) somehow resist these threats, and either need everlasting political support from the outside, or, in case of its absence, are objectively and inevitably doomed to internal instability and chaos. Consequently, it is argued that the role of external players in maintaining order, especially in a strategically conditioned environment of the region, would always remain crucial.

Even more unpleasant aspect of misperception, in particular, for Kazakhstan has been the global view of it as a dangerous post-Soviet state because of its nuclear resources, and a more or less reasonable suspicion in this connection affected also South Asian states. For example, in the early 1990s, a number of experts rightly pointed to the strategic importance for India and Pakistan of military-industrial cooperation with Kazakhstani side, in which the nuclear sector was bound to play a major role. Indeed, at that time between India and Pakistan there has started a latent confrontation for the opportunity to obtain any degree of access to Kazakhstani nuclear weapons and technologies. Moreover, India quite early received from Kazakhstan proposals for interaction in the nuclear field; in his turn, Pakistan with Kazakhstan's accession to the Organisation of Economic Cooperation was accused by many actors of the world community in having for an object the obtaining of nuclear technologies from Kazakhstani side. What is more amusing, the nuclear arsenal and technologies of Kazakhstan appeared to be a special cause for concern for India and Pakistan themselves because of possibility of their transfer to only one of the two opposing South Asian states. Despite categorical objections even by the representatives of Kazakhstani higher echelon, these fears tended to intensify as a result of a distorted perception of this situation by Western countries, who called Kazakhstan 'the first Muslim nuclear power'. Of particular concern in this regard were the 
United States, which in fact had no doubt that the transfer by the republics of the Central Asian region of nuclear raw materials and technologies to Pakistan was only a matter of time [9, p. 19-20], that in turn caused even greater incorrect perception of this issue by Indians and Pakistanis themselves. This tangle of distorted perception of the Republic of Kazakhstan as a subject of direct or indirect nuclear threat was naturally annihilated by the very fact of its refusal to possess nuclear weapons. However, as the saying runs, it is difficult to please everyone, and this refusal was again ambiguously perceived, in particular, by the same South Asian states - if officially their politicians welcomed this step of Kazakhstani side, then the writings of Indian and Pakistani experts demonstrated their doubts about its expediency. Though, it was not so much about the very fact of Kazakhstan's refusal to possess nuclear weapons, but about the doubtfulness of all guarantees and conditions provided by foreign powers in return for this refusal. In any case, such 'residual' undesirable moments in perception should always be borne in mind by Kazakhstani side.

Another important point in this regard lies in the confidence of many South Asian researchers and officials that, on the analogy of the notorious Indian-Pakistani confrontation, there are serious contradictions between the Central Asian republics up to conflict ones, which also have a negative impact on stability within the region. First of all, what is at issue is 'historically preconditioned' territorial, resource, ethnic, confessional and similar disputes, right up to the opinion that the states of Central Asia are involved into the constant game of contradictions in mutual relations. Hence, representatives of South Asia (as well as many other foreigners) do not entirely see and know in Central Asia things which, in particular, Kazakhstan is so much proud of and which can solidly add to its information security - that is, social tolerance and success of integration initiatives.

It is also important to note here that although Indian authors do understand and invariably emphasize in their works that they interpret Central Asia predominantly as the five republics of the region formerly being part of the Soviet Middle Asia, but in reality they, in analogy with their South Asian neighbours, often include in this concept also the Chinese Eastern Turkestan and, what is more problematically, Afghanistan. At that, everything that ends in '-stan' (with the exception of Hindustan and the names of some Indian states) has unfortunately mostly negative, frightening colour in Indian public opinion and is associated with Islamism, fundamentalism, extremism, terrorism and other threats to peaceful development of humankind.

Again, in all of the abovementioned one can see, among other things, the confidence in old statement by Z. Brzezinski - often (and quite uncritically) used in the works of Indian and Pakistani authors - about Central Asia as a 'global zone of percolating violence' [10, p. 53]. Therefore, it is necessary to repeat that one should not blame only representatives of South Asia for such inaccurate or erroneous views regarding intra- and interstate situation of Central Asian republics.

A Point of Economic Development. As for the question of raw materials orientation of economies of the Central Asian states, here one also can run across rather categorical judgments that, despite its huge raw material reserves, Central Asia is still economically too weak and backward in technology, and acts as an appendage to the economies of more developed states. Even in recent works of Indian researchers five Central Asian states were classified merely on the basis of what energy resources they possess. Thus, it is stated that as far as oil is concerned, of importance are Kazakhstan and Turkmenistan, and Uzbekistan is important mostly for gas while Kyrgyzstan and Tajikistan - for water-power resources; no other aspects of their economic development were attached equal importance.

However, in this case such an opinion of South Asian authors is based not only and even not so much upon the judgments of foreign researchers or own delusions, but upon the impersonal generally known statistical data on the items of trade between India and Pakistan on one side and the Central Asian republics on another. Indeed, the latter mainly supply the former with raw materials in exchange for finished goods.

At the same time, if in the earliest studies of Indians and Pakistanis it was often said that in Central Asia they enjoy almost unlimited possibilities in terms of versatile training of local cadres, in later works one can see a more balanced view upon the true state of things. Nowadays, for example, Indians identify only a few areas in which their experience is undoubtedly more significant comparing to this in Central Asian states (such as high and information technologies, management in global markets, etc.). In other respects, they recognize the high level of training of local specialists in a number of areas, as well as the 
fact of almost hundred-percent literacy of population of Central Asian countries. (The question of training of Indian and Pakistani students in medical institutions of higher education in Central Asian countries stands aloof and requires separate consideration.)

A Point of Uzbekistan versus Kazakhstan. If to consider the issue of perception in terms of attitude of India and Pakistan towards the individual states of the Central Asian region and their related priorities here, it should be noted that during the 1990's and even at the beginning of the XXI century both South Asian states associated (and in some cases, for example, in historical and cultural interaction - continue to associate) the whole Central Asia with Uzbekistan. This is explained by a number of objective and subjective reasons.

Firstly, Indians got quite used to the fact that relations of their country with Central Asia during the Soviet period mainly came to Indian-Uzbek contacts, when Uzbekistan was represented as in all respects advanced Central Asian republic to invite foreign delegations in. For Pakistan, such a statement is even more topical - in particular, in the difficult period of the beginning of Soviet troops' intervention into Afghanistan, a Soviet ambassador to Pakistan was Sarvar Azimov - a representative of the Uzbek Soviet Socialist Republic.

Secondly, Indians and Pakistanis uncritically trust in a statement that the Great Mughals, who came to South Asia from the territory of modern Uzbekistan, were ethnic Uzbeks. In addition, during the Great Game of the XIX century and gradual absorption of Central Asia by the Russian Empire, contacts of South Asian merchants and political emigrants with Bukhara, Khorezm, Tashkent and other Uzbek sites were the longest and most active comparing to the rest of Central Asia.

Thirdly, immediately after the collapse of the Soviet Union, India's and Pakistan's contacts with independent Uzbekistan turned out to be more vivacious and versatile in comparison, for example, with Kazakhstan and, in particular, out of all the Central Asian republics, the Consulate General of India in Tashkent was the first to become an Embassy.

Fourthly, the fact of Uzbekistan's central geographical position in the entire region of Central Asia along with its status of most densely populated country of the region is also hold by many, and not only in South Asia. Moreover, the opinion of Western specialists who for a long time called Uzbekistan 'the center of attraction in Central Asia' also played certain role for South Asians.

Fifthly, assessing the current situation in Central Asia, representatives of South Asia for lack of fresh information from inside the region itself, sometimes easily rely upon data of ten to even twenty years' prescription, when Uzbekistan in many aspects indeed occupied leading positions in Central Asian space. In addition, it should be noted that during that very period the military authority of Kazakhstan suffered in the eyes of India and Pakistan (contrary to Western states) after it became a nuclear-free state, and representatives of two South Asian nuclear powers are still thinking about what Kazakhstan has won from this.

Sixthly (and this should become a kind of good lesson for Kazakhstan and other Central Asian countries), Uzbekistan is quite successful in its 'cultural' (public) diplomacy, at least on the South Asian direction. Using his centuries-old experience, but even more proper sensus communis as it is, Uzbekistan self-propagates itself in rather reasonable way, including dissemination in India and Pakistan of literature about its achievements in not only English, but also in Hindi and Urdu languages respectively.

As a result, the overall impression of Central Asia has long been based mainly on assessments of situation predominantly in Uzbekistan, and the popular saying of Indian and Pakistani authors that, barring geographical location and language, there is no difference between Central Asia and Kashmir could be considered as somewhat correct only if Central Asia is equated to Uzbekistan (to some extent - Tajikistan and Turkmenistan), but not to Kazakhstan. Therefore, India and Pakistan gradually become accustomed to the current state of affairs in Central Asia, where Kazakhstan has been building up its lead. Fortunately, the factor of CICA played its positive role in political sense, and in terms of economy at present South Asians are already well aware that their main trading partner in the region is Kazakhstan, at least because it accounts for the bulk of the entire Indian and Pakistani trade with the Central Asian republics, and that without Kazakhstan the region would not be of such economic interest for South Asia.

Discussion. These are main (however, far from exhaustive) characteristics given by Indian and partly Pakistani intellectuals as well as the general public to the states of Central Asia. At that, some of these characteristics do not simply incorrectly or exaggeratedly reflect the actual situation in the overall region 
and its individual states, but in some cases even completely contradict it. From the point of information security this fact deserves close attention, first of all, of representatives of the Central Asian republics themselves.

In general, major difference between the newest works by South Asian researchers and those written earlier lies, in the first place, in a greater amount of impartial information about the Central Asian region that is now available to them. As for the very views on Central Asia set forth in previous and current works, it can be said that in general, many erroneous provisions continue to be repeated. Perhaps earlier these provisions were expressed in more categorical form and, being based on less amount of accessible information, had even greater share of preposterous conclusions. Nowadays, there is a more correct and balanced approach in the works of Indian and Pakistani experts, and there are more reservations regarding the suggested statements. Nevertheless, unfortunately (and Central Asians themselves are the first to bear responsibility for this), the information and overall knowledge gained by Indians and Pakistanis about Central Asia is still not enough to form a more adequate view of the region, and even in the most recent works one can find extensive positive references to incorrect statements that have been expressed ten or even twenty years ago.

Certainly, a whole number of South Asian scientists at present create works in which an analysis of affairs in Central Asia and future prospects of their cooperation with South Asian states is based upon wise approach and critical use of sources attracted. Indians and Pakistanis freely emphasize mistakes and inaccuracies, like those mentioned in this paper, in the writings of both domestic and foreign colleagues, and are becoming increasingly aware that from Western sources which they are forced to use for lack of others, they receive not the most reliable information about the countries of Central Asian region. It should be noted here that as far back as 2005 (!), an Indian researcher A. Dhaka has wisely pointed out that "among the major steps required is to discourage the game-like mindset so much proliferated by Western media and intellectuals around these [Central Asian - Ye.R.] states" [11, p. 185]. And it is worth doing justice to Indian and Pakistani experts on the history of Central Asia, which they know not much worse comparing to Central Asian historians themselves, and treat it without excessive nationalist aspirations comparing to the latter.

Moreover, the author of this paper does not exclude the probability that under the 'inaccuracies' in, say, India's views of Central Asian states there in fact lies a kind of political game. So, for instance, speaking of quite significant influence of Islamic factor upon stability in the region, India can actually set itself the following goals: a) to win Central Asian republics over for more dynamic cooperation in the fight against a real threat of Islamic radicals; b) to insure itself against the growth of Islamic extremism in Central Asia through a preventive reminder of this to regional states with predominantly Muslim population; c) to get an opportunity of more thorough participation in the political affairs of Central Asian states on the basis of the need to protect their 'secular values'. In this case, a 'correction' of such the Indian 'mistakes', certainly, would require somewhat different approach on the part of the representatives of Central Asia.

And yet, even with all possible assumptions, it cannot be denied that South Asians in general are still not fully aware of certain aspects related to the Central Asian region and its individual states.

For fair, Indians and even more so Pakistanis themselves, while getting acquainted with scientific and analytical works by Kazakhstani and other Central Asian researchers devoted to their countries, can also find a number of inaccurate or even incorrect, distorted moments. These, among other things, include a certain arrogance in respect of abundant positive experience and recent achievements of these South Asian states due to the mere lack of proper knowledge of many of these remarkable achievements; an exaggeration of severity of the Kashmir problem, up to the confidence in severe impact of this conflict upon everyday lives of Indians and Pakistanis, etc. What is more, India should no more perceive as once and for all given the 'positive attitude of Central Asian people' towards her (since, for instance, in Kazakhstan this attitude currently shifts from positive to positively neutral and in some cases even indifferent), but contrary should be persistent and insistent, and time after time propagate itself through various means not limited by only dance, yoga and cinema. On the contrary, Pakistan should not in the same way interpret once prevalent chilly attitude towards him as present-day one; though Indian image in 
the eyes of Central Asians still seems to be better, but currently Pakistan also is not perceived by them in previous inimical manner.

The problem lies also in the fact that often as an argument on the need to develop comprehensive cooperation between the states of Central and South Asia there are adduced not any actual data reflecting the current interest of these states in each other on the basis of current situation as well, but some vague clauses about 'historically conditioned interaction' and appeals for 'restoration of forgotten traditions' of the Great Silk Road. It should be said that any solid historical background of any brisk cooperation, of course, is a significant addition to the development of this cooperation at present stage; however, it could remain a positive element of only historical memory in case of absence of real initiatives related to modern prospects.

Nevertheless, comparing all the above-mentioned derelictions of mutual perception, it can be argued that representatives of Central Asia still know more about South Asia in comparison to what Indians and Pakistanis know about the former, and not only because of a higher level of all-stages education in Central Asia, but also because India (and, to a lesser extent, Pakistan) themselves more effectively use the instruments of 'cultural', or public, diplomacy.

Therefore, based on the data presented in this paper, there can be drawn three main final conclusions.

First, the representatives of neither India nor Pakistan are interested in a mistaken view of states of Central Asian region. On the contrary, they render an invaluable service to the representatives of these states since, by studying various inaccuracies encountered in their writings, the Central Asians themselves can see and assess the actual objective weaknesses of their 'cultural' diplomacy, self-positioning in the world arena and overall information security.

Second, Indians and Pakistanis should more meticulously study at least developmental strategies and programs of separate Central Asian states (which are often published in English in the official websites of governmental bodies), as they contain the exact information about this or that country's actual developmental aspects, priorities and prospects (based on which South Asian countries can not only obtain more correct information, but also suggest certain, specific and not just notorious 'all-round and allembracing' aspects for cooperation). Besides, both South Asian countries, despite difficulty and even considerable unwillingness, should try to rather utilize the advantages of Russian rather than English language in presenting their strong sides in the Central Asian milieu.

Third, India and Pakistan can offer Central Asians their both positive and negative, but in any case important experience and expertise in the field of public diplomacy, which would then require rational study, reasonable adaptation and proper utilization by the latter.

For the more peoples, countries and regions know about each other, the better are chances of their closer and more fruitful interaction.

\section{REFERENCES}

[1] Thussu, D.K. (2013). Communicating India's Soft Power: Buddha to Bollywood. New York: Palgrave Macmillan. ISBN: 1-137-02788-6.

[2] Aziz, S. (2016). Chief Guest's Address at the Inaugural Session. In: Report on Seminar 'Pakistan's Soft Power', 8 April 2016. Islamabad: Institute of Strategic Studies, 5-6.

[3] Rudenko, Ye.I. (2010). The Issues of Mutual Perception in India's Relations with Central Asian States [Problemy vzaimnogo vospriyatiya v otnosheniyakh Indii s gosudarstvami Tsentral'noy Azii]. In: Young Orientalists of the Commonwealth of Independent States (collected articles) [Molodyye vostokovedy stran Sodruzhestva Nezavisimykh Gosudarstv. Sbornik statey]. Moscow: Institute of Oriental Studies at the Russian Academy of Sciences, 127-147 (in Russ.).

[4] Rudenko, Ye.I. (2015). Aspects of Kazakhstani Statehood in the Eyes of Indian Side [Faktory kazakhstanskoy gosudarstvennosti v vospriyatii indiyskoy storony]. In: Evolution of Kazakh Statehood: Historical Traditions and Challenges of the XXI Century [Evolyutsiya kazakhskoy gosudarstvennosti: istoricheskiye traditsii $i$ vyzovy XXI veka]. Astana: Kazakh Humanities and Law University, 159-163 (in Russ.).

[5] Mir, G.M. (2006). Regional Interdependence and Viable Resource Sharing Mechanism in CAS. In: M.A. Kaw and A.A. Banday, eds. Central Asia: Introspection. Srinagar: University of Kashmir, 239-254.

[6] Starr, S.F. (2005). A 'Greater Central Asia Partnership' for Afghanistan and Its Neighbors. Silk Road Paper Series of Central Asia-Caucasus Institute \& Silk Road Studies Program. Washington: Central Asia-Caucasus Institute.

[7] Ministry of Defence, 2000-01. Annual Report of the Ministry of Defence. New Delhi: Government of India.

[8] Ministry of Defence, 2016-17. Annual Report of the Ministry of Defence. New Delhi: Government of India.

[9] Khan, R. (1992). Emergence of Central Asia and Its Relevance to India. Mainstream 30, no. 24:15-22. 
[10] Brzezinski, Z. (1997). The Grand Chessboard: American Primacy and Its Geostrategic Imperatives. New York: Basic Books. ISBN: 0-465-02725-3.

[11] Dhaka, A. (2005). South Asia and Central Asia: Geopolitical Dynamics. Jaipur: Mangal Deep Publications. ISBN: 8175-94181-6.

УДК 303.633.4(64:51)+327.821

\title{
Е.И. Руденко
}

Р.Б. Сүлейменов атындағы Шығыстану институты, Алматы, Қазақстан

\author{
ОРТАЛЫҚ ПЕН ОНТУСТІК АЗИЯ МЕМЛЕКЕТТЕРІ АРАСЫНДАҒЫ \\ ҰҒЫНУДЫҢ БҰРМАЛАНУЫ - «ЖҰМСАҚ КУШ» ФАКТОРЫ МЕН АҚПАРАТТЫҚ \\ ҚАУІПСІЗДІКТІҢ ПРОБЛЕМАСЫ РЕТІНДЕ
}

\begin{abstract}
Аннотация. Мақала Қазақстанға айрықша көңіл бөле отырып, Орталық Азия республикалары ішіндегі және онан тысқары қалыптасқан жағдайлардың әртүрлі қырларын Үндістан мен Пакистан өкілдерінің ұғынуындағы бірқатар қателіктер мен олқылықтарды қарастыруды алдына мақсат етіп қойған. Әдіснамалық жұмыс Оңтүстік Азияның екі үздік мемлекет өкілдерінің бірталай зерттеу және сарапшы еңбектерін сынап талдау негізінде жүргізілген. Онан басқалары ішінде, Орталық Азия аймағындағы ішкі және сыртқы қауіпсіздік, діни фактор мен экономикалық даму мәселелері қозғалған. Объективтік себептермен, үнділер мен пакистандықтар орталықазиялық жағдайды зерделеу мен оны көрсетуде, көбінесе ескірген материалдарды, оның ішінде, батыс және ресейлік авторлардың сыңар жақ жазылған жұмыстарын, сонымен қатар, өздерінің қате болжамдары мен ойша пайымдауларын қоса тартқандығы көрсетілген. Сонымен бірге, мақала оңтүстіказиялық зерттеушілердің осы проблеманы еңсеруге бағытталған талпыныстарына да мегзейді. Қорыта келе, «жұмсақ күш» факторы мен оған сәйкес Орталық Азия республикаларының ақпараттық қауіпсіздігінде шынында да осал жерлері бар және келтірілген нақты мысалдар мен қағидалардың, сондайақ, Оңтүстік Азия елдері тәжірибесі негізінде, ұғынуда атап өтілген олқылықтардың барлығы да оларды азайту немесе/және жою мақсатында орынды еленуі абзал деген шешімге тоқтау жасайды.

Түйін сөздер: Оңтүстік және Орталық Азия, ұғынудың бұрмалануы, жұмсақ (ақылды) күш, ақпараттық қауіпсіздік, мәдени (қоғамдық) дипломатия, қауіп-қатер.
\end{abstract}

\section{Е.И. Руденко}

Институт востоковедения им. Р.Б. Сулейменова, Алматы, Казахстан

\section{ИСКАЖЕННОСТЬ ВОСПРИЯТИЯ МЕЖДУ ГОСУДАРСТВАМИ ЦЕНТРАЛЬНОЙ И ЮЖНОЙ АЗИИ КАК ПРОБЛЕМА ФАКТОРА «МЯГКОЙ СИЛЫ» И ИНФОРМАЦИОННОЙ БЕЗОПАСНОСТИ}

Аннотация. Статья ставит своей целью рассмотрение ряда ошибок и неточностей в восприятии представителями Индии и Пакистана различных аспектов ситуации, складывающейся внутри и вокруг республик Центральной Азии, с особым акцентом на Казахстан. Методологически работа проведена на основе критического анализа значительного числа исследовательских и экспертных трудов представителей двух государств-лидеров Южной Азии. Среди прочих затронуты вопросы внутренней и внешней безопасности, религиозного фактора и экономического развития в регионе Центральной Азии. Показано, что главным образом в силу объективных причин индийцы и пакистанцы привлекают к изучению и отображению центральноазиатской ситуации зачастую устаревшие материалы, включая нередко предвзято написанные работы западных и российских авторов, а также собственные ошибочные предположения и умозаключения. Вместе с тем, статья также указывает на попытки южноазиатских исследователей, направленные на преодоление данной проблемы. В заключение делается вывод о том, что в факторе «мягкой силы» и, соответственно, информационной безопасности республик Центральной Азии действительно имеются слабые моменты, и что на основе приведенных конкретных примеров и положений, а также опыта самих стран Южной Азии все перечисляемые ошибки в восприятии должны быть разумно учтены с целью их минимизации или/и ликвидации.

Ключевые слова: Южная и Центральная Азия, искаженное восприятие, мягкая (умная) сила, информационная безопасность, культурная (общественная) дипломатия, угрозы.

Information about author:

Rudenko Yelena I. - Doctorate in History, Senior Research Fellow, Central and South Asia Department of the R.B. Suleimenov Institute of Oriental Studies. 


\section{МАЗМҰНЫ}

Беспаева Р.С., Бугубаева Р.О., Мануэль Ф. Грела2. Көрсеткіштердің теңдестірілген жүйесі негізінде Щучинск-Бурабай курорттық аймағын дамытудың кешенді стратегиясын қалыптастыру ................................................................................ 5

Аюпова 3.К., Құсайынов Д.Ө.Азаматтық процесстерді жетілдірудегі интеграцияның кейбір қырлары...................... 13

Құсайынова А. А., Вальдемар Козловски, Геращенко И. П.Қазақстан республикасындағы міндетті әлеуметтік сақтандырудың қаржылық-құқықтық тетіктерінің ерекшеліктері.

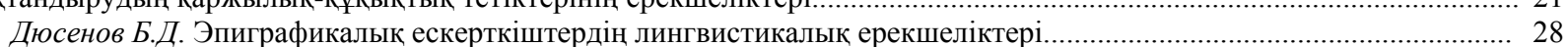

Джумадилова Ш.Г., Атабай Б.Ж. Қазақстандағы халықтың жинақтарының динамикасы......................................... 33

Карабалина А.А., Альситова А. Б., Кереймаганбетова Ж.Н., Абишева Н. М. Құндылық - рухани-адамгершілік

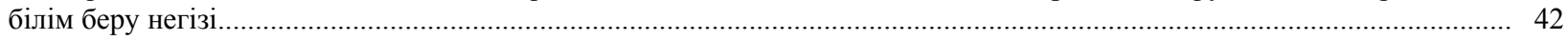

Кенжебаева Д.К., Өрмөрза Б. Ғ., Дашгин Махаммадли. Қазақстандық заманауи жастардың құндылығы............. 51

Нурманова А.Ш., Медерова Д.Е., Дюсенов Б.Д. «Бөкейхан әулетінің талдыбейіт қорымы» эпиграфикалық ескерткіштері тарихи дереккөз ретінде.

Кыдырова Ж.Ш., Онласынов Е.З., Абишова А.У., Шадиева А.А. Оңтүстік Қазақстан облысы сүт және сүт өнімдері нарығындағы жағдайды зерттеу ......

Абимова Г.У., Аманжолов Р., Мынбаева Б.Н., Ибрагимова Д.И. ЖОО-да биолог-студенттердің жобаларды

ұйымдастырылуы мен орындалуына даярлығы.......

Балтабаева А.Ю., Ризаходжаева Г. Мәдени интеграция үдерісіндегі жібек жолының феномені............................... 9

Бурганова Р.И., Абдугалина С.Е., Туякова А.Е. Студенттерге бағытталған білім беру арқылы білім сапасын

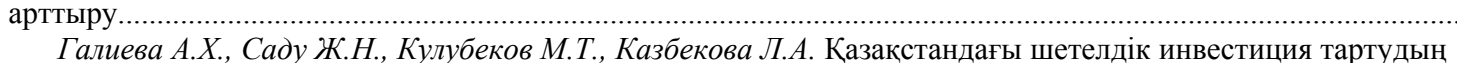

институционалдық жағдайын (талаптарын) бағалау..

Джалилов 3.Г., Батырхан Б.Ш. ХX ғ. екінші жартысындағы шетелдік исламтанушылардың ислам және саясат

туралы теориялық дискурсы.......

Джумабекова А.Т., Канатова А.Ж. Қаржылық ынтымақтастық жағдайларындағы Қазақстан республикасының

ұлттық банкінің өткізу механизмінің өзгеруі......

Дүйсен Г. М., Айтжанова Д. А. Қазақстан және Орталық Азия елдеріндегі көші-қон процесстері дамуының мәселелері мен ерекшеліктері

Есендұлова М.Н. Қазақстандағы « Қиын балаларды» оңалтудың және әлеуметтендірудің психологиялық ерекшеліктері

Жакишева К.М., Жуманова Д.Т., Мукашева Г.М. Экономиканың аграрлық секторының тұрақты дамуына арналған ауыл шаруашылық кәсіпорындарының қаржылық шарттарын мониторингінің рөлі.....

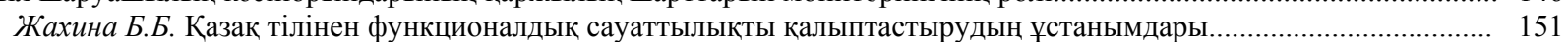

Идресова У.Х., Садуахасова 3.Ж., Муханова А.Т. Криминалистика....................................................................... 156

Савельева В. В. Қазақстандағы кредит технологиясын пайдалану және дамуының тарихи және педагогикалық базасы.

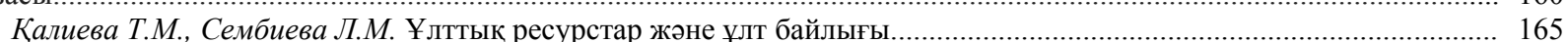

Каримова Р.У., Хаджиева Г.У. ҚХР Ұлттық саясаты контексіндегі ШҰАА-ның этносаяси және әлеуметтікэкономикалық трансформациясы мәселесі.

Керімбек Г., Молдашбаева Л., Джрауова Қ., Ажмухамедова А., Мизанова А. Қазақстан республикасының

республикалық бюджетіне түсетін салық түсімдерінің көрсеткіштерін талдау және бағалау.....

Жолдасбекова С.А., Парманкулова П.Ж., Асаналиев М.К. Мүмкіндігі шектеулі балаларды дамытудағы ұлттық ойындар

Молдакенова Е.К., Байгабулова К.К., Онаева Б.Т. БҚО-да инновациялық үрдістерді басқарудың аймақтық

аспектілігі жүйесінің дамудың жолдары.

Мұратова Г.К., Шаушенова А.Г., Жумасеитова С.Д., Онұварбаева М.Б.Білім беру үрдісінде бұлттық

технологияларын қолдану......

Несіпбеков E. Н., Аппакова Г.Н. Кәсіпорынның инвестициялық портфелін қалыптастырудың теориялық

Нургабылов М.Н., Барлыков Е.К., Егембердиева С.М. ҚР есеп өнеркәсібінің дамуының басқаруының трендсі....... 220

Нурымбетов Т.Я., Абишова А.У., Уразбаева Г.Ж., Кыдырова Ж.Ш., Байнеева П.Т., Абишо Н.У. Модернизациялық

жағдайындағы қр халқын әлеуметтік қолдауының басымдықтары.....

Рахимова С. А., Тургумбекова М. М. Қазақстан республикасындағы шағын және орта бизнестіңмемлекеттік қолдау

бағдарламалары және олардың тиімділігін жүзеге асыру шаралары.......................................................................... 233

Руденко Е.И. Орталық пен Оңтүстік Азия мемлекеттері арасындағы ұғынудың бұрмалануы - «Жұмсақ күш»

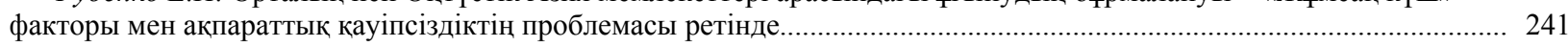

Тохтабаева Ш. Қазына-сандық.......................................................................................................... 251

Утепкалиева К.М., Сабирова Р.К., Кенбаева Г.У. Мұнай-газ секторындағы мемлекеттік-жеке серіктестікті дамыту

Мыңбаев Д. Е. Банкте басқару есебін ұйымдастыру тұжырымдамасы...

Султанова Г.С. Жаңа формацияның экономисі - бакалаврдың кәсіби құзыреттілігін қалыптастырудың

Шаяхметова А.А. Университет жағдайында инклюзивті білім беру үшін педагогтарды оқыту....... 


\section{СОДЕРЖАНИЕ}

Беспаева Р.С., Бугубаев Р.О., Мануэль Ф. Грела. Формирование комплексной стратегии развития ЩучинскоБоровской курортной зоны на основе сбалансированной системы показателей. Аюпова 3.К., Кусаинов Д.У., Уинстон Наган. Некоторые грани интеграции в совершенствовании гражданского процесса.

Кусаинова А.А., Козловски Вальдемар, Геращенко И.П. Обзор некоторых особенностей финансово-правового механизма обязательного социального страхования в республике Казахстан......

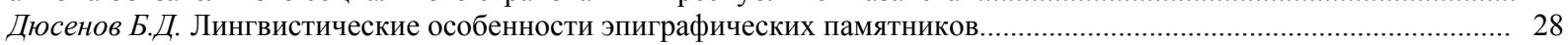

Джумадилова Ш.Г., Атабай Б.Ж.Динамика сбережений населения в Казахстане................................................... 33

Карабалина А.А., Альситова А. Б., Кереймаганбетова Ж.Н., Абишева Н. М. Ценность как базовая основа духовнонравственного образования.

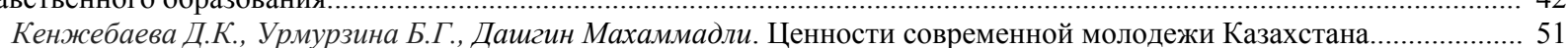

Нурманова А.Ш., Медерова Д.Е., Дюсенов Б.Д. Эпиграфические памятники «Некрополи талдыбейит династии

Бокейхановых» как исторический источник.

Кыдырова Ж.Ш., Онласынов Е.З., Абишова А.У., Шадиева А.А.Исследование ситуации на рынке молока и молочной продукции южно-казахстанской области

Абишова Г.У., Аманжолов Р., Мынбаева Б.Н., Ибрагимова Д.И. Готовность студентов-биологов к организации

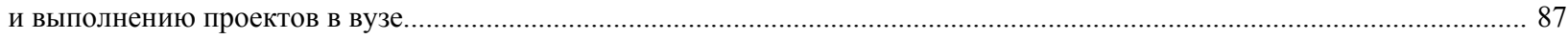

Балтабаева А.Ю., Ризаходжаева Г. Феномен великого шелкового пути в процессе культурной интеграции............... 91

Бурганова Р.И., Абдугалина С.Е., Туякова А.Е. Повышение качества образования посредством

студентоцентрированного обучения...

Галиева А.Х., Саду Ж.Н., Кулубеков М.Т., Казбекова Л.А. Оценка институциональных условий привлечения

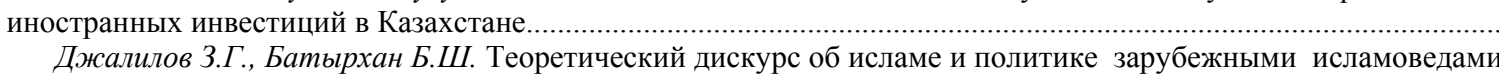
второй половины ХX в.

Джумабекова А.Т., Канатова А.Ж. Трансформация трансмиссионного механизма национального банка республики

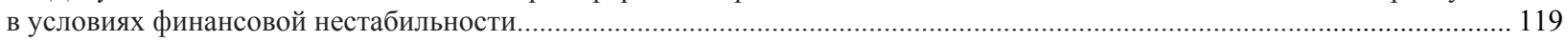

Дуйсен Г.М., Айтжанова Д.А. Проблемы и особенности развития миграционных процессов в Казахстане

и странах Центральной Азии.

Есенгулова М.Н. Психологические особенности реабилитации и социализации "Трудных подростков"

в Казахстане".

Жакишева К.М., Жуманова Д.Т., Мукашева Г.М.Роль мониторинга финансового состояния сельскохозяйственных

предприятий в обеспечении устойчивого развития аграрного сектора экономики.........................................................146

Жахина Б.Б. Принципы формирования функциональной грамотности казахского языка.......................................... 151

Идресова У.Х., Садуахасова 3.Ж., Муханова А.Т. Криминалистика......................................................................... 156

Савельева B.B. Исторические и педагогические основы формирования и разработки кредитной технологии

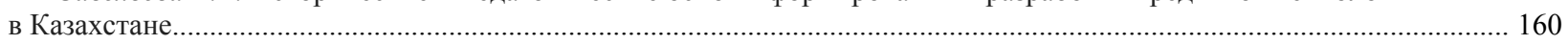

Калиева Т.М., Сембиева Л.М. Национальные ресурсы и богатство нации.................................................. 165

Каримова Р.У., Хаджиева Г.У. К вопросу об этно-политической и социально-экономической трансформации

СУАР в контексте национальной политики КНР

Керимбек Г., Молдашбаева Л., Джрауова Қ., Ажмухамедова А., Мизанова А. Анализ и оценка показателей

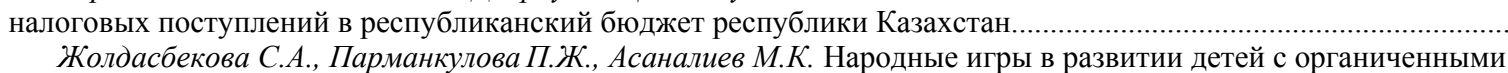

Жолдасбекова С.А., Парманкулова П.Ж., Асаналиев М.К. Народные игры в развитии детей с органиченными

Молдакенова Е.К., Байгабулова К.К., Онаева Б.Т.Пути развития системы регионального аспекта управления

инновационными процессами в АПК.

Муратова Г.К., Шаушенова А.Г., Жумасеитова С.Д., Онгарбаева М.Б. Применение облачных технологий

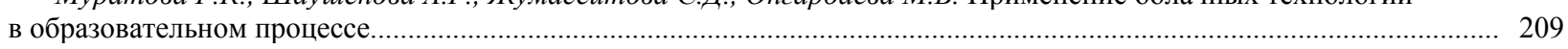

Несипбеков Е.Н., Аппакова Г.Н. Теоретические аспекты формирования инвестиционного портфеля предприятия. 214

Нургабылов М.Н., Барлыков Е.К., Егембердиева С.M. Тенденции управления развитием мясоперерабаты-

вающей отрасли в РК.

Нурымбетов Т.Я., Абишова А.У., Уразбаева Г.Ж., Кыдырова Ж.Ш., Байнеева П.Т., Абишов Н.У. Приоритеты

социальной поддержки населения РК в условиях модернизации................................................................................. 22

Рахимова С. А., Тургумбекова М. М. Программы государственной поддержки мсб в республике Казахстан и меры

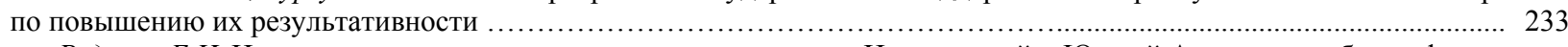

Руденко Е.И. Искаженность восприятия между государствами Центральной и Южной Азии как проблема фактора

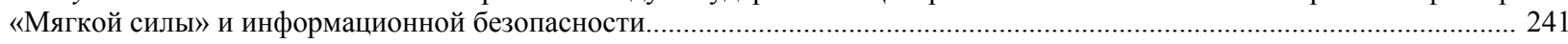

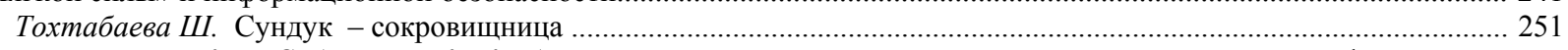

Утепкалиева К.М., Сабирова Р.К., Кенбаева Г.У.Развитие государственно-частного партнерства в нефтегазовой

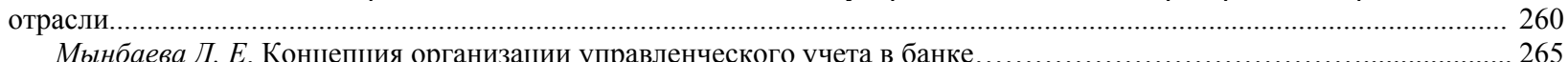

Мынбаева Д. Е. Концепция организации управленческого учета в банке...........................................2.
Султанова Г.С. Педагогические аспекты формирования профессиональных компетенций бакалавра - экономиста

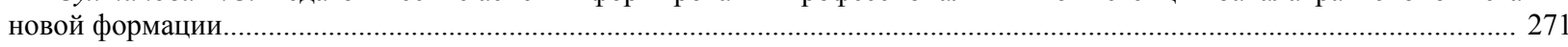

Шаяхметова А.А. О подготовке педагогических кадров к инклюзивному образованию в условиях вуза................ 277 


\section{CONTENTS}

Bespayeva R.S., Bugubayeva R.O., Manuel F. Grela. Formation of the complex strategy for development of the Schuchinsk-

Burabay resort area based on the balanced system of indicators.

Ayupova Z.K., Kussainov D.U., Winston Nagan. Some facets of integration in themodernization ofthe civil process..............13

Kussainova A.A., Kozlowski Waldemar, Gerashchenko I.P. The review of some features of the financial legal mechanism of obligatory social insurance in the republic of Kazakhstan...

Dyussenov B.D. Linguistic features of epigraphic monuments................................................................................ 28

Jumadilova Sh.G., Atabay B.Zh. Dynamics of the population savings in Kazakhstan.......................................................... 33

Karabalina A.A., Alsitova A.B., Kereimaganbetova Zh.N., Abisheva N.M. The values as critical factor of moral education... 42

Kenzhebayeva D.K., Urmurzina B.G., Dashqin Mahammadli. The modern youth values in Kazakhstan............................. 51

Nurmanova A.S., Mederova D.E., Dyussenov B.D. "Bokeykhanov dynasty taldybeyit necropolis" epigraphic monuments

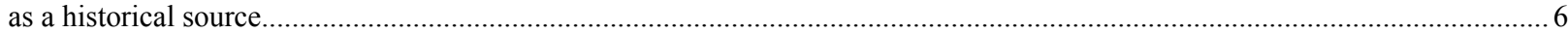

Kydyrova Zh.Sh., Onlasynov E.Z., Abishova A.U., Shadieva A.A.Research of the situation in the market of milk and dairy

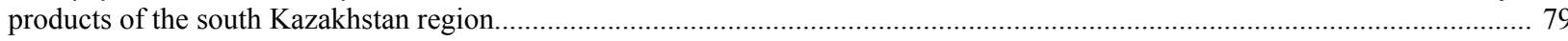

Abishova G.U., Amanzholov R.A., Mynbayeva B.N., Ibragimova D.I. Readiness of students-biologists for the organization

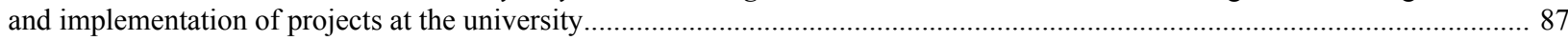

Baltabayeva A.Y., Rizakhojayeva $G$. The phenomenon of the great silk road in the cultural integration process................... 91

Burganova R.I., Abdugalina S.E., Tuyakova A.E. Improving the quality of education through student-centered education... 102

Galiyeva A.Kh., Sadu Zh.N., Kulubekov M.T., Kazbekova L.A. Assessment of the institutional terms of the foreign

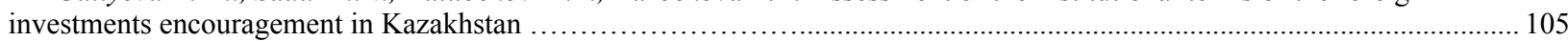

Dzhalilov Z.G. Theoretical discourse on islam and politics in foreign humanism of the second half of 20th century.......... 112

Dzhumabekova A.T., Kanatova A.ZH. Transformation of the transmission mechanism of the national bank of the republic

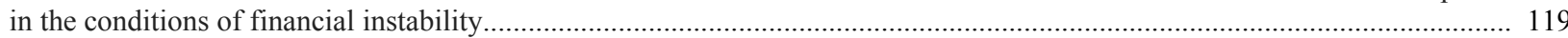

Suleimenov R.B. Problems and features of the development of migration processes in Kazakhstan and Central Asia.......... 124

Yesengulova M.N. Psychological aspects of reintegration and resocialization of "Trouble" adolescents in Kazakhstan....... 134

Zhakisheva K.M., Zhumanova D.T., Mukasheva G.M.The role of monitoring the financial condition of agricultural

enterprises in ensuring sustainable development of the agrarian sector of the economy......................................................... 146

Zhakhina B.B. Principles of functional literacy formation of the kazakh language....................................................... 151

Idresova U.Kh., Saduahasova Z.Zh., Mukhanova A.T. Criminalistics............................................................................. 156

Savelyeva $V . V$. Historicalandpedagogical bases of formation and development of credit technology in Kazakhstan........... 160

Kaliyeva T.M., Sembiyeva L.M. National Resources and national wealth.................................................................. 165

Karimova R., Hajiyeva G. Examining ethno-political and SOCIO-economic transformation of the xinjiang uyghur

autonomous region in the context of the PRC national policies........................................................................................ 176

Kerimbek G., Moldashbayeva L., Jrauova K., Azhmukhamedova A., Misanova A. Analysis and evaluation of reduction

of tax recovery of the republic of kazakhstan on the budget of the republic of Kazakhstan................................................. 185

Zholdasbekova S.A., Parmankulova P.Zh., Assanaliyev M.K. Folk games in the education of children with physical, mental and sensory disturbances..

Moldakenova E.K., Baygabulova K.K., Onaeva B.T. Ways of development of the system of the regional aspect of managing innovative processes in the APC.

Muratova G.K., Shaushenova A.G., Zhumassseitova C.D., Ongarbayeva M.B. Application of cloud technologies in the educational process......

Nurgabylov M.N., Barlikov E.K., Egemberdieva S.M. Trends of management of the development of meat processing industry in RK

Nurymbetov T.Ya., Abishova A.U., Urazbaeva G.Zh., Kydyrova Z.Sh., Baineeva P.T., Abishov N.U. Priorities of social support of the population of republic of Kazakhstan in the conditions of modernization........

Rakhimova S. A., Turgumbekova M. M. Programs of government support for sme in the republic of Kazakhstan and measures to enhance their efficiency.....

Rudenko Ye.I. Misperception between the states of Central and South Asia as a 'Soft power' and information security issue...

Tokhtabayeva Sh. Zh. Treasure-chest.

Utepkalieva K.M., Sabirova R.K., Kenbaeva G.U.Development of public private partnership approach in oil and gas

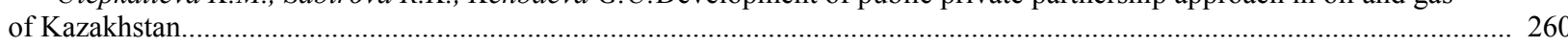

Mynbayeva D.E. Concept of organization of management accounting in bank ........................................................... 265

Sultanova G. S. Pedagogical aspects of formation of professional competence of the bachelor-economist of the new formation

Shayakhmetova A.A. On the training of teaching staff for inclusive education under the conditions of higher education institution. 


\section{PUBLICATION ETHICS AND PUBLICATION MALPRACTICE IN THE JOURNALS OF THE NATIONAL ACADEMY OF SCIENCES OF THE REPUBLIC OF KAZAKHSTAN}

For information on Ethics in publishing and Ethical guidelines for journal publication see http://www.elsevier.com/publishingethics and http://www.elsevier.com/journal-authors/ethics.

Submission of an article to the National Academy of Sciences of the Republic of Kazakhstan implies that the work described has not been published previously (except in the form of an abstract or as part of a published lecture or academic thesis or as an electronic preprint, see $\mathrm{http} / / / \mathrm{www} . e l s e v i e r . c o m / p o s t i n g p o l i c y)$, that it is not under consideration for publication elsewhere, that its publication is approved by all authors and tacitly or explicitly by the responsible authorities where the work was carried out, and that, if accepted, it will not be published elsewhere in the same form, in English or in any other language, including electronically without the written consent of the copyrightholder. In particular, translations into English of papers already published in another language are not accepted.

No other forms of scientific misconduct are allowed, such as plagiarism, falsification, fraudulent data, incorrect interpretation of other works, incorrect citations, etc. The National Academy of Sciences of the Republic of Kazakhstan follows the Code of Conduct of the Committee on Publication Ethics (COPE), and follows the COPE Flowcharts for Resolving Cases of Suspected Misconduct (http://publicationethics.org/files/u2/New_Code.pdf). To verify originality, your article may be checked by the originality detection service Cross Check http://www.elsevier.com/editors/plagdetect.

The authors are obliged to participate in peer review process and be ready to provide corrections, clarifications, retractions and apologies when needed. All authors of a paper should have significantly contributed to the research.

The reviewers should provide objective judgments and should point out relevant published works which are not yet cited. Reviewed articles should be treated confidentially. The reviewers will be chosen in such a way that there is no conflict of interests with respect to the research, the authors and/or the research funders.

The editors have complete responsibility and authority to reject or accept a paper, and they will only accept a paper when reasonably certain. They will preserve anonymity of reviewers and promote publication of corrections, clarifications, retractions and apologies when needed. The acceptance of a paper automatically implies the copyright transfer to the National Academy of sciences of the Republic of Kazakhstan.

The Editorial Board of the National Academy of sciences of the Republic of Kazakhstan will monitor and safeguard publishing ethics. 
Правила оформления статьи для публикации в журнале смотреть на сайте:

\section{www:nauka-nanrk.kz}

\section{social-human.kz}

Редакторы М.С. Ахметова, Т.А. Апендиев, Д.С. Аленов

Верстка на компьютере А.М. Кульгинбаевой

Подписано в печать 08.12.2018

Формат 60x881/8. Бумага офсетная. Печать - ризограф.

17,7 п.л. Тираж 500. Заказ 6.

Национальная академия наук $Р К$

050010, Алматы, ул. Шевченко, 28, т. 272-13-18, 272-13-19 